\title{
EKSTRAKSI CIRI CACAT PENGELASAN PADA CITRA DIGITAL FILM RADIOGRAFI MENGGUNAKAN GEOMETRIC INVARIANT MOMENT DAN STATISTICAL TEXTURE
}

\author{
MUHTADAN \\ Sekolah Tinggi Teknologi Nuklir \\ Badan Tenaga Nuklir Nasional - BATAN \\ JL.Babarsari Kotak Pos 6101 YKBB, Yogyakarta 55281 \\ E-mail:muhtadan@gmail.com
}

\begin{abstract}
Abstrak
EKSTRAKSI CIRI CACAT PENGELASAN PADA CITRA DIGITAL FILM RADIOGRAFI MENGGUNAKAN GEOMETRIC INVARIANT MOMENT DAN STATISTICAL TEXTURE. Penelitian ini dilakukan untuk mendapatkan ekstraksi ciri cacat pengelasan pada citra digital film radiografi dengan menggunakan metode geometric invariant moment dan statistical texture. Nilai ekstraksi ciri ini dapat dimanfaatkan sebagai nilai yang digunakan dalam melakukan klasifikasi dan pengenalan pola cacat pada interpretasi cacat pengelasan citra digital film radiografi secara otomatis oleh komputer. Jenis cacat yang digunakan dalam penelitian ini adalah longitudinal crack, transversal crack, distributed porosity, clustered porosity, wormhole dan tanpa cacat (no defect). Sebagai bahan penelitian digunakan citra digital film radiografi dengan keenam jenis defektologi tersebut. Langkah yang dilakukan yaitu dengan membuat program untuk membaca citra digital, kemudian melakukan pemotongan citra (cropping) untuk melokalisasi letak cacat kemudian menghitung nilai momen dengan persamaan metode geometric invariant moment dan statistical texture. Hasil penelitian berupa nilai-nilai ekstraksi ciri yang telah diuji dengan perlakuan RST(rotation, scale, transformation) dan diperoleh nilai momen yang paling invariant terhadap RST yaitu momen $\phi_{3}, \phi_{4}, \phi_{5}$ dari metode geometric invariant moment . Sedangkan dari metode statistical texture digunakan seluruh nilai sebagai hasil ekstraksi ciri yaitu intensitas rerata , kontras rerata, smoothness, $3^{\text {rd }}$ moment, uniformity, dan entropy
\end{abstract}

Kata kunci: Ekstraksi ciri, film radiografi, geometric invariant moment, statistical texture

\begin{abstract}
FEATURE EXTRACTION OF WELD DEFECTOLOGY IN DIGITAL IMAGE OF RADIOGRAFHIC FILM USING GEOMETRIC INVARIANT MOMENT AND STATISTICAL TEXTURE. The purpose of this research is to perform feature extraction in weld defect of digital image of radiographic film using geometric invariant moment and statistical texture method. Feature extraction values
\end{abstract}


can be use as values that used to classify and pattern recognition on interpretation of weld defect in digital image of radiographic film by computer automatically. Weld defectology type that used in this research are longitudinal crack, transversal crack, distributed porosity, clustered porosity, wormhole, and no defect. Research methodology on this research are program development to read digital image, then performing image cropping to localize weld position, and then applying geometric invariant moment and statistical texture formulas to find feature values. The result of this research are feature extraction values that have tested with RST (rotation, scale, transformation) treatment and yield moment values that more invariant there are $\phi_{3}$, $\phi_{4}, \phi_{5}$ from geometric invariant moment method. Feature values from statistical texture that are average intensity, average contrast, smoothness, $3^{\text {rd }}$ moment, uniformity, and entropy, they used as feature extraction values.

Keywords: Feature extraction, radiographic film, geometric invariant moment, statistical texture.

\section{PENDAHULUAN}

Salah satu aplikasi teknologi nuklir yang banyak dimanfaatkan dalam dunia industri adalah penggunaan sumber radioaktif untuk uji tak merusak (non destructive test). Radiografi industri merupakan salah satu metode dalam bidang uji tak rusak yang digunakan untuk mendeteksi kerusakan atau cacat dari suatu material menggunakan sumber radiasi (umumnya dengan sinar-x dan sinar gamma). Radiasi yang dipancarkan sumber diserap oleh benda kerja ketika radiasi menembusnya. Cacat dan material sekitarnya menyerap jumlah radiasi yang berbeda. Sehingga terjadi perbedaan intensitas radiasi yang mengenai film yang digunakan sebagai media perekam. Hal tersebut menghasilkan sejumlah gambar atau bayangan cacat material pada film radiografi.

Kemampuan operator radiografi untuk menginterpretasikan cacat dalam radiografi dipengaruhi kondisi penerangan dalam ruang pengamatan, dan tingkat pengenalan berbagai pola atau ciri-ciri dalam citra. Keahlian seseorang dalam melakukan interpretasi film sangat dipengaruhi oleh pengalaman dilapangan dan pengalaman yang diperoleh dari literatur standar cacat radiografi.

Perkembangan teknologi dewasa ini membuat sistem komputer memiliki kemampuan komputasi tinggi untuk meningkatkan pengolahan data menjadi sebuah informasi. Salah satu data tersebut bisa berupa gambar atau citra digital suatu film radiografi yang mampu diolah untuk mendapatkan informasi yang lebih baik dan efisien karena pengolahan data tersebut dilakukan oleh sistem komputer.

Informasi dari suatu film radiografi diantaranya adalah pola dari diskontinuitas pada film yang menunjukkan cacat yang terjadi pada suatu 
spesimen atau benda uji yang dilakukan uji tak rusak dengan radiografi. Penglihatan mesin atau computer vision mampu menghasilkan informasi dari suatu objek misal citra digital sehingga dapat mengenali pola untuk bisa diolah lebih lanjut dalam mendapatkan informasi secara otomatis. Namun agar komputer mampu melakukan pengenalan cacat pengelasan pada citra digital film radiografi, maka citra digital tersebut perlu dilakukan ekstraksi ciri dari pola cacat sebagai ciri spesifik yang dimiliki suatu cacat yang selanjutnya dapat dianalisis oleh komputer untuk dilakukan pengenalan cacat secara otomatis.

Penelitian ini bertujuan untuk mendapatkan ciri (feature) khusus dari cacat pengelasan pada film radiografi sehingga ciri tersebut dapat digunakan sebagai pola-pola spesifik suatu cacat pengelasan untuk melakukan klasifikasi atau identifikasi cacat secara otomatis oleh komputer. Ekstraksi ciri secara umum dianggap sebagai sebuah proses pemetaan pengukuran obyek awal menjadi ciri yang lebih efektif ${ }^{[1]}$. Metode yang digunakan untuk melakukan ekstraksi ciri yaitu geometric invariant moment dan statistical texture.

\section{DASAR TEORI}

\section{Geometric Invariant Moment}

Ekstraksi ciri suatu obyek dapat dilakukan dengan berbagai metode, baik statistik maupun sintaksis. Salah satu metode untuk mendapatkan ciri obyek, dalam hal ini untuk citra, dapat digunakan metode Invaiant Moments. Metode ini dapat digunakan sebagai pendeskripsi bentuk berdasarkan teori dari moment.

Geometric invariant moments pertamakali diperkenalkan oleh Hu. Teknik ini dipilih untuk melakukan ekstraksi ciri citra sejak ciri-ciri yang diperoleh adalah Rotation Scale Translation (RST)-invariant ${ }^{[2]}$.

Moment suatu fungsi banyak digunakan dalam teori probablitas, namun beberapa properti dapat diperoleh dari moment yang juga dapat diterapkan untuk analisis bentuk Himpunan momen suatu fungsi $f(x, y)$ dari dua variabel didefinisikan sebagai berikut ${ }^{[3]}$.

$$
\mathrm{m}_{\mathrm{pq}}=\int_{-\infty}^{\infty} \int_{-\infty}^{\infty} \mathrm{x}^{\mathrm{p}} \mathrm{y}^{\mathrm{q}} \mathrm{f}(\mathrm{x}, \mathrm{y}) \mathrm{dxdy} \quad \mathrm{p}, \mathrm{q}=0,1,2, \ldots
$$

Sedangkan momen dua dimensi dengan orde $(p+q)$ dari suatu citra digital dengan ukuran $\mathrm{M} \times \mathrm{N}$ didefinisikan sebagai ${ }^{[4]}$. 


$$
\mathrm{m}_{\mathrm{pq}}=\sum_{\mathrm{x}=0}^{\mathrm{M}-1} \sum_{\mathrm{y}=0}^{\mathrm{N}-1} \mathrm{x}^{\mathrm{p}} \mathrm{y}^{\mathrm{q}} \mathrm{f}(\mathrm{x}, \mathrm{y})
$$

dimana $p=0,1,2, \ldots$ dan $q=0,1,2, \ldots$ adalah integer. Selanjutnya momen pusat (central moments) orde $(p+q)$ didefinisikan sebagai

$$
\mu_{\mathrm{pq}}=\sum_{\mathrm{x}=0}^{\mathrm{M}-1} \sum_{\mathrm{y}=0}^{\mathrm{N}-1}(\mathrm{x}-\overline{\mathrm{x}})^{\mathrm{p}}(\mathrm{y}-\overline{\mathrm{y}})^{\mathrm{q}} \mathrm{f}(\mathrm{x}, \mathrm{y})
$$

untuk $p$ dan $q$ adalah $0,1,2, \ldots$, dimana

$$
\overline{\mathrm{x}}=\frac{\mathrm{m}_{10}}{\mathrm{~m}_{00}} \text { dan } \overline{\mathrm{y}}=\frac{\mathrm{m}_{01}}{\mathrm{~m}_{00}}
$$

Kemudian normalized central moments, yang dinotasikan dengan $\eta_{p q}$, didefinisikan sebagai berikut ${ }^{[4]}$.

$$
\eta_{\mathrm{pq}}=\frac{\mu_{\mathrm{pq}}}{\mu_{00}^{\gamma}}
$$

dimana

$$
\gamma=\frac{\mathrm{p}+\mathrm{q}}{2}+1
$$

untuk $p+q=2,3,4, \ldots$.

Sehingga ketujuh nilai invariant moments dapat diturunkan dari moment kedua dan ketiga.

$$
\begin{aligned}
& \phi_{1}=\eta_{20}+\eta_{02} \\
& \phi_{2}=\left(\eta_{20}+\eta_{02}\right)^{2}+4 \eta_{11}^{2} \\
& \phi_{3}=\left(\eta_{30}-3 \eta_{12}\right)^{2}+\left(3 \eta_{21}-\eta_{03}\right)^{2} \\
& \phi_{4}=\left(\eta_{30}+\eta_{12}\right)^{2}+\left(\eta_{21}+\eta_{03}\right)^{2}
\end{aligned}
$$




$$
\begin{aligned}
\phi_{5}= & \left(\eta_{30}-3 \eta_{12}\right)\left(\eta_{30}+\eta_{12}\right)\left[\left(\eta_{30}+\eta_{12}\right)^{2}-3\left(\eta_{21}+\eta_{03}\right)^{2}\right] \\
& +\left(3 \eta_{21}-\eta_{03}\right)\left(\eta_{21}+\eta_{03}\right)\left[3\left(\eta_{30}+\eta_{12}\right)^{2}-\left(\eta_{21}+\eta_{03}\right)^{2}\right] \\
\phi_{6}= & \left(\eta_{20}-\eta_{02}\right)\left[\left(\eta_{30}+\eta_{12}\right)^{2}-3\left(\eta_{21}+\eta_{03}\right)^{2}\right] \\
& +4 \eta_{11}\left(\eta_{30}+\eta_{12}\right)\left(\eta_{21}+\eta_{03}\right) \\
\phi_{7}= & \left(3 \eta_{21}-\eta_{03}\right)\left(\eta_{30}+\eta_{12}\right)\left[\left(\eta_{30}+\eta_{12}\right)^{2}-3\left(\eta_{21}+\eta_{03}\right)^{2}\right] \\
+ & \left(3 \eta_{12}-\eta_{30}\right)\left(\eta_{21}+\eta_{03}\right)\left[3\left(\eta_{30}+\eta_{12}\right)^{2}-\left(\eta_{21}+\eta_{03}\right)^{2}\right]
\end{aligned}
$$

Nilai ketujuh moment tersebut tidak berubah terhadap translasi, perubahan skala, pencerminan (mirroring) dan rotasi ${ }^{[4]}$.

\section{Statisical Texture}

Suatu pendekatan penting untuk melakukan deskripsi region adalah menghitung kandungan teksturnya (texture content). Meskipun tidak ada definisi formal mengenai tekstur, namun deskriptor ini memberikan pengukuran properti seperti kehalusan (smoothness), kekasaran (coarseness), dan keteraturan (regularity). Terdapat tiga prinsip pendekatan untuk mendeskripsikan tekstur region yaitu statistik, struktural dan spektral ${ }^{[4]}$.

Pendekatan statistikal merupakan salah satu pendekatan mudah untuk mendeskripsikan teksture yaitu dengan menggunakan moment statistik dari histogram intensitas suatu citra atau region.

Jika suatu variabel acak $z$ yang menotasikan intensitas, dan $p\left(z_{i}\right)$ merupakan histogramnya dengan $i=0,1,2, \ldots, L-1, L$ merupakan jumlah level intensitas, maka moment ke-n dari $z$ terhadap rerata adalah

$$
\mu_{\mathrm{n}}(\mathrm{z})=\sum_{\mathrm{i}=0}^{\mathrm{L}-1}\left(\mathrm{z}_{\mathrm{i}}-\mathrm{m}\right)^{\mathrm{n}} \mathrm{p}\left(\mathrm{z}_{\mathrm{i}}\right)
$$

dimana $m$ adalah nilai rerata $z$ (rerata intensitas):

$$
\mathrm{m}=\sum_{\mathrm{i}=0}^{\mathrm{L}-1} \mathrm{z}_{\mathrm{i}} \mathrm{p}\left(\mathrm{z}_{\mathrm{i}}\right)
$$

Berdasarkan Persamaan (14) maka nilai $\mu_{0}=1$ dan $\mu_{1}=0$ merupakan nilai momen ke-0 dan ke-1. Momen kedua atau $\mu_{2}$ disebut dengan varians $\sigma^{2}(z)$ merupakan bagian penting dalam deskripsi tekstur. Momen tersebut adalah pengukuran kontras intensitas yang dapat memberikan deskripsi kehalusan relatif (relative smoothness). Karena nilai varian cenderung menjadi besar 
untuk citra grayscale, maka variance dapat dinormalisasi dengan interval $[0$, 1]. Normalisasi dilakukan dengan membagi varian terhadap $(L-1)^{2}$.

Standar deviasi yang dinotasikan dengan $\sigma(z)$, juga sering digunakan sebagai suatu pengukuran tekstur.

Momen ketiga,

$$
\mu_{3}(\mathrm{z})=\sum_{\mathrm{i}=0}^{\mathrm{L}-1}\left(\mathrm{z}_{\mathrm{i}}-\mathrm{m}\right) 3 \mathrm{p}\left(\mathrm{z}_{\mathrm{i}}\right)
$$

merupakan pengukuran dari kecondongan (skewness) histogram sedangkan moment keempat $\mu_{2}$ merupakan pengukuran kedataran relatif (realtive flatness).

Pengukuran tekstur lain yang dapat digunakan sebagai deskripsi suatu citra berdasarkan histogramnya adalah pengukuran keseragaman (uniformity) yaitu

$$
\mathrm{U}(\mathrm{z})=\sum_{\mathrm{i}=0}^{\mathrm{L}-1} \mathrm{p}^{2}\left(\mathrm{z}_{\mathrm{i}}\right)
$$

dan pengukuran suatu entropi rerata (average entropy) yaitu

$$
\mathrm{e}=-\sum_{\mathrm{i}=0}^{\mathrm{L}-1} \mathrm{p}\left(\mathrm{z}_{\mathrm{i}}\right) \log _{2} \mathrm{p}\left(\mathrm{z}_{\mathrm{i}}\right)
$$

Karena $p$ memliki rentang nilai $[0,1]$ dan penjumlahannya sama dengan 1 , pengukuran $U$ adalah maksimum untuk suatu citra dengan semua tingkat keabuannya sama (keseragaman maksimal), dan berkurang dari nilai maksimal tersebut. Entropi adalah pengukuran keberubahan (variability) dan bernilai 0 untuk citra yang konstan.

\section{Histogram citra}

Histogram suatu citra digital dengan rentang level intensitas [0, L-1] adalah fungsi diskrit $h\left(r_{k}\right)=n_{k}$, dimana $r_{k}$ adalah nilai intensitas ke- $k$ dan $n_{k}$ adalah jumlah piksel dalam citra dengan intensitas $r_{k}$. Hal tersebut merupakan penerapan umum untuk melakukan normalisasi suatu histogram dengan cara membagi setiap komponen dengan jumlah seluruh piksel dalam citra, yang dinotasikan dengan produk $M N$, dimana $M$ dan $N$ merupakan ukuran baris dan kolom citra. Sehingga normalisasi histogram yaitu

$$
\mathrm{p}\left(\mathrm{r}_{\mathrm{k}}\right)=\frac{\mathrm{r}_{\mathrm{k}}}{\mathrm{MN}}
$$

dengan $k=0,1,2, \ldots, \mathrm{L}-1$. 
Sehingga $p\left(r_{k}\right)$ atau histogram adalah estimasi dari probabilitas kejadian level intensitas $r_{k}$ pada suatu citra. Penjumlahan dari seluruh komponen suatu normalisasi histogram sama dengan satu ${ }^{[4]}$.

\section{METODE PENELITIAN}

\section{Bahan}

Bahan penelitian yang digunakan untuk melakukan penelitian ini adalah film radiografi dalam bentuk citra digital (file) yang diperoleh dari data film radiografi versi IIW (International Institute of Welding).

\section{Alat}

Alat yang digunakan adalah komputer dengan spesifikasi yang cukup untuk menjalankan perangkat lunak Matlab di atas sistem operasi Windows XP Service Pack 3.

\section{Cara Kerja}

Citra digital film radiografi yang digunakan adalah film radiografi yang memiliki cacat pengelasan longitudinal crack, transversal crack, distributed porosity, clustered porosity, wormhole dan no defect. Selanjutnya melakukan langkah-langkah sebagai berikut.

1. Membuat program untuk membaca citra digital film radiografi, baik dalam format .bmp maupun .jpg. kemudian melakukan pemotongan citra (cropping) untuk melokalisasi citra yang terdapat cacat.

2. Membuat program untuk menghitung nilai geometric invariant moments dan statistical texture.

3. Menguji hasil ekstraksi ciri dengan geometric invariant moment dengan berbagai variasi perubahan geometri.

Citra digital film radiografi yang digunakan memiliki format .bmp atau .jpg, untuk itu program membaca citra digital film radiografi dirancang untuk membaca kedua format tersebut.

File bmp atau bitmap merupakan format umum untuk menyimpan citra bitmap yang dikembangkan oleh Microsoft dan digunakan sebagai citra yang tidak terkompresi (uncompressed images). Sedangkan jpeg atau Joint Photographic Experts Group merupakan standar citra kualitas fotografi.

Pengembangan aplikasi interpretasi citra film radiografi ini diprogram untuk membaca citra format bmp dan jpeg karena proses digitisasi dari film radiografi menggunakan kamera digital yang umum, dan karena citra keluaran kamera digital umumnya berformat jpeg atau bmp.

Pemilihan ROI (Region of Interest) mengurangi operator dalam memperlakukan pada bagian yang tidak berguna dalam citra, sehingga mengurangi waktu komputasi. Keuntungan kedua adalah untuk mengurangi 
pengolahan yang berbasis pada pendekatan global untuk menggunakan wilayah yang tidak relevan dalam citra, yang dapat memberikan efek negatif pada hasil keluaran ${ }^{[5]}$.

Pemilihan wilayah dalam citra yang diduga memiliki cacat pengelasan ini dapat dilakukan dengan pemotongan (cropping) citra. Secara umum, ukuran citra film radiografi memiliki lebar (width) yang lebih besar daripada tingginya (height), sehingga dalam melakukan pemotongan citra dilakukan dengan memotong menjadi ukuran $300 \times 100$ piksel.

Pemotongan citra dilakukan terlebih dahulu dengan menentukan titik atau beberapa piksel yang diduga memiliki cacat pengelasan, kemudian secara otomatis program akan menentukan lokasi pemotongan citra dengan titik tengah dari hasil pemotongan merupakan koordinat piksel yang dipilih tersebut, berikut algoritma untuk melakukan pemotongan suatu citra $f$ dalam aplikasi ini:

1. Tentukan koordinat $(x, y)$ dari piksel pada citra $f$ yang diduga terdapat cacat.

2. Cari koordinat awal untuk pemotongan dengan langkah:

a. $X_{\min }=x-150$

b. $Y_{\min }=y-50$

c. Jika $X_{\min }<0$, maka $X_{\min }=0$

d. Jika $Y_{\text {min }}<0$, maka $Y_{\min }=0$

e. Jika $X_{\min }>$ (lebar citra $\left.f-300\right)$, maka $X_{\min }=$ lebar citra $f-300$

f. $Y_{\min }<$ (lebar citra $\left.f-100\right)$, maka $Y_{\min }=$ lebar citra $f-100$

3. Memotong citra $f$ menjadi citra $g$ dengan

a. Untuk $i=1$ hingga 300, lakukan b

b. Untuk $j=j$ hingga 100 , lakukan

c. $g(m, n)=f(i, j)$, untuk $m=1,2,3 \ldots 300$, dan $n=1,2,3 \ldots 100$

Pembuatan program untuk menghitung nilai geometric invariant moments dilakukan dengan mengikuti pada Persamaan (2) hingga Persamaan (13), kemudian untuk menghitung nilai statistical texture dilakukan terlebih dahulu dengan mencari nilai distribusi skala keabuan dari citra atau histogramnya.

Pengujian dilakukan dengan memerikan variasi perubahan geometri pada citra digital film radiografi untuk tiap jenis cacat, adapun variasi tersebut dilakukan dengan melakukan operasi RST (Rotation Scalling and Translation) yaitu meliputi rotasi, penskalaan, pencerminan dan translasi dengan rincian sebagai berikut.

a. Rotasi $30^{\circ}$ dan $175^{\circ}$.

b. Penskalaan dengan ukuran 0,5 kali dan 4 kali dari ukuran citra sebelumnya.

c. Pencerminan vertikal dan horisontal. 
Gambar 1 menunjukkan diagram alir pelaksanaan penelitian untuk melakukan ekstraksi ciri cacat pengelasan pada citra digital film radiografi.

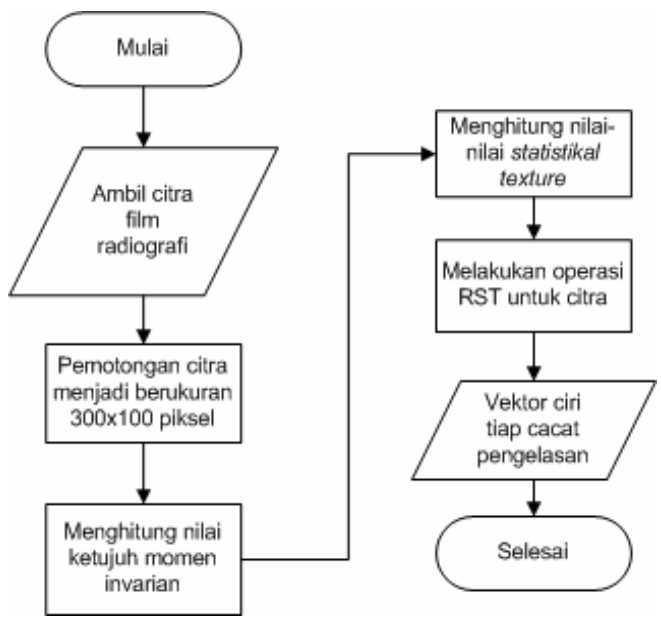

Gambar 1. Diagram Alir Pelaksanaan Penelitian

\section{HASIL DAN PEMBAHASAN}

Sampel citra digital film radiografi yang digunakan dalam penelitian ini yaitu meliputi citra digital film radiografi dengan cacat yang sesuai dengan standar IIW ditunjukkan dalam Gambar 2.

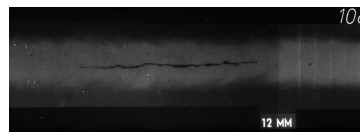

a

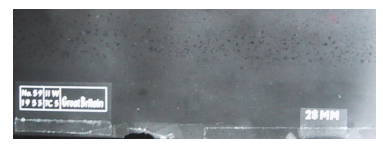

c

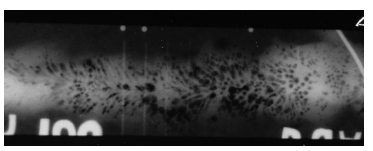

$\mathrm{e}$

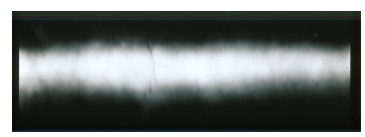

b

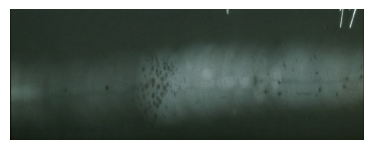

d

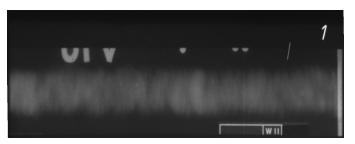

$\mathrm{f}$

Gambar 2. Sampel Citra Digital yang Digunakan dalam Penelitian,

(a) Longitudinal Crack, (b) Transversal Crack, (c) Distributed Porosity, (d) Clustered Porosity, (e) Wormhole, (f) No Defect. 
Citra digital yang telah dilakukan pembacaan dari program yang dibuat, selanjutnya dilakukan proses pemotongan (cropping) sehingga diperoleh citra digital yang berukuran $300 \times 100$ yang ditunjukkan pada Gambar 3 berikut.

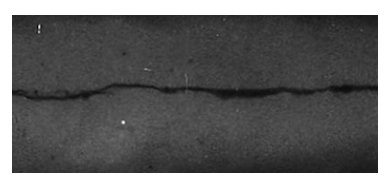

a

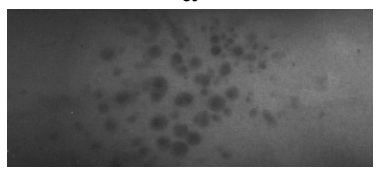

d

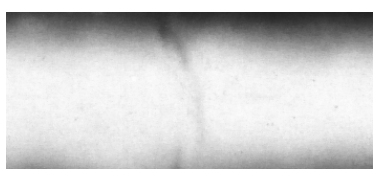

b



$\mathrm{e}$

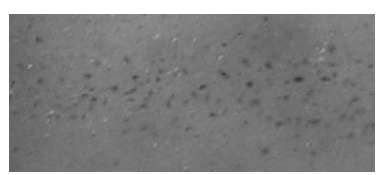

c

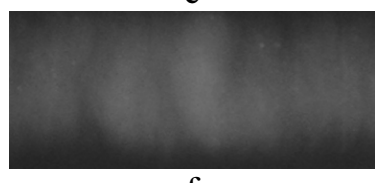

f

Gambar 3. Hasil Pemotongan Citra,(a) Longitudinal Crack, (b) Transversal Crack, (c) Distributed Porosity, (d) Clustered Porosity, (e) Wormhole, dan (f) No Defect

Citra digital hasil pengolahan awal menggunakan pemotongan citra selanjutnya dilakukan penghitungan nilai geometric invariant moments dari program yang telah dibuat. Tabel 1 merupakan hasil ekstraksi ciri menggunakan geometric invariant moment.

Tabel 1. Hasil Tujuh Nilai Geometric Invariant Moment Masing-Masing Sampel

\begin{tabular}{ccccccc}
\hline $\begin{array}{c}\text { Nilai } \\
\text { invarian } \\
(|\ln |)\end{array}$ & $\begin{array}{c}\text { Longitu- } \\
\text { dinal } \\
\text { crack }\end{array}$ & $\begin{array}{c}\text { Trans- } \\
\text { versal } \\
\text { crack }\end{array}$ & $\begin{array}{c}\text { Distributed } \\
\text { porosity }\end{array}$ & $\begin{array}{c}\text { Clustered } \\
\text { Porosity }\end{array}$ & $\begin{array}{c}\text { Worm- } \\
\text { hole }\end{array}$ & $\begin{array}{c}\text { No } \\
\text { defect }\end{array}$ \\
\hline$\phi_{1}$ & 1.0373 & 2.2887 & 1.6985 & 1.8879 & 0.5560 & 1.4281 \\
$\phi_{2}$ & 0.2977 & 1.855 & 0.8599 & 0.0245 & 0.6709 & 0.1147 \\
$\phi_{3}$ & 5.0746 & 10.011 & 10.143 & 4.4974 & 3.0309 & 10.899 \\
$\phi_{4}$ & 5.4276 & 11.097 & 9.926 & 4.4452 & 3.0484 & 12.976 \\
$\phi_{5}$ & 10.709 & 21.988 & 19.999 & 8.9169 & 6.0948 & 25.04 \\
$\phi_{6}$ & 5.2949 & 12.208 & 10.359 & 4.4362 & 2.7147 & 12.954 \\
$\phi_{7}$ & 12.554 & 22.519 & 21.623 & 11.535 & 8.5049 & 25.778 \\
\hline
\end{tabular}

Hasil pada Tabel 1 merupakan nilai ketujuh geometric invariant moments dari citra awal. Selanjutnya untuk membuktikan bahwa nilai momen tersebut tak berubah (invariant) terhadap perubahan geometri citra maka dilakukan pengujian dengan melakukan operasi RST dan dan menghitung nilai momennya yang meliputi penskalaan dua kali dan setengan kali citra awal, 
rotasi $30^{\circ}$ dan $145^{\circ}$, serta pencerminan horisontal dan vertikal. Tabel 2 hingga Tabel 7 merupakan hasil dari pengujian ini.

Tabel 2. Nilai Geometric Invariant Moment untuk Cacat Longitudinal Crack Dalam Perlakuan RST

\begin{tabular}{cccccccc}
\hline $\begin{array}{c}\text { Nilai } \\
\text { invarian } \\
(\ln \mid)\end{array}$ & $\begin{array}{c}\text { Citra } \\
\text { Awal }\end{array}$ & $\begin{array}{c}\text { Pen- } \\
\text { skalaan } \\
\text { 2 kali }\end{array}$ & $\begin{array}{c}\text { Pen- } \\
\text { skalaan } \\
0,5 \mathrm{kali}\end{array}$ & $\begin{array}{c}\text { Rotasi } \\
30^{\circ}\end{array}$ & $\begin{array}{c}\text { Rotasi } \\
145^{\circ}\end{array}$ & $\begin{array}{c}\text { Pen- } \\
\text { cerminan } \\
\text { horisontal }\end{array}$ & $\begin{array}{c}\text { Pen- } \\
\text { cerminan } \\
\text { vertikal }\end{array}$ \\
\hline$\phi_{1}$ & 1.0373 & 1.0459 & 1.0331 & 0.5752 & 0.6322 & 1.3292 & 1.0254 \\
$\phi_{2}$ & 0.2977 & 0.3088 & 0.2921 & 0.3623 & 0.3838 & 0.4466 & 0.2903 \\
$\phi_{3}$ & 5.0746 & 5.0591 & 5.0824 & 5.0744 & 5.0747 & 5.0746 & 5.0746 \\
$\phi_{4}$ & 5.4276 & 5.4137 & 5.4345 & 5.4274 & 5.4276 & 5.4276 & 5.4276 \\
$\phi_{5}$ & 10.709 & 10.679 & 10.724 & 10.709 & 10.709 & 10.709 & 10.709 \\
$\phi_{6}$ & 5.2949 & 5.2748 & 5.3048 & 6.1337 & 5.8993 & 5.2203 & 5.2985 \\
$\phi_{7}$ & 12.554 & 12.542 & 12.561 & 12.105 & 12.55 & 13.005 & 13.005 \\
\hline
\end{tabular}

Tabel 3. Nilai Geometric Invariant Moment untuk Cacat Transversal Crack Dalam Perlakuan RST

\begin{tabular}{cccccccc}
\hline $\begin{array}{c}\text { Nilai } \\
\text { invarian } \\
(|\mathrm{n}|)\end{array}$ & $\begin{array}{c}\text { Citra } \\
\text { Awal }\end{array}$ & $\begin{array}{c}\text { Pen- } \\
\text { skalaan } \\
2 \text { kali }\end{array}$ & $\begin{array}{c}\text { Pen- } \\
\text { skalaan } \\
0,5 \text { kali }\end{array}$ & Rotasi $30^{\circ}$ & $\begin{array}{c}\text { Rotasi } \\
145^{\circ}\end{array}$ & $\begin{array}{c}\text { Pen- } \\
\text { cerminan } \\
\text { horisontal }\end{array}$ & $\begin{array}{c}\text { Pen- } \\
\text { cerminan } \\
\text { vertikal }\end{array}$ \\
\hline$\phi_{1}$ & 2.2887 & 2.2977 & 2.2842 & 1.8352 & 1.9049 & 2.4079 & 2.2164 \\
$\phi_{2}$ & 1.855 & 1.8425 & 1.8613 & 2.4291 & 2.4953 & 1.7982 & 1.8938 \\
$\phi_{3}$ & 10.011 & 9.977 & 10.029 & 10.011 & 10.011 & 10.011 & 10.011 \\
$\phi_{4}$ & 11.097 & 11.057 & 11.117 & 11.098 & 11.098 & 11.097 & 11.097 \\
$\phi_{5}$ & 21.988 & 21.901 & 22.032 & 21.989 & 21.989 & 21.988 & 21.988 \\
$\phi_{6}$ & 12.208 & 12.159 & 12.232 & 13.325 & 11.939 & 12.179 & 12.227 \\
$\phi_{7}$ & 22.519 & 22.452 & 22.553 & 22.068 & 22.097 & 23.199 & 23.199 \\
\hline
\end{tabular}

Tabel 4. Nilai Geometric Invariant Moment untuk Cacat Distributed Porosity Dalam Perlakuan RST

\begin{tabular}{cccccccc}
\hline $\begin{array}{c}\text { Nilai } \\
\text { invarian } \\
(\ln \mid)\end{array}$ & $\begin{array}{c}\text { Citra } \\
\text { Awal }\end{array}$ & $\begin{array}{c}\text { Pen- } \\
\text { skalaan } \\
2 \text { kali }\end{array}$ & $\begin{array}{c}\text { Pen- } \\
\text { skalaan } \\
0,5 \text { kali }\end{array}$ & $\begin{array}{c}\text { Rotasi } \\
30^{\circ}\end{array}$ & $\begin{array}{c}\text { Rotasi } \\
145^{\circ}\end{array}$ & $\begin{array}{c}\text { Pen- } \\
\text { cerminan } \\
\text { horisontal }\end{array}$ & $\begin{array}{c}\text { Pen- } \\
\text { cerminan } \\
\text { vertikal }\end{array}$ \\
\hline$\phi_{1}$ & 1.6985 & 1.711 & 1.6924 & 1.3749 & 1.0764 & 1.6952 & 1.7079 \\
$\phi_{2}$ & 0.8599 & 0.8534 & 0.86311 & 1.3625 & 1.7527 & 0.8618 & 0.8546 \\
\hline
\end{tabular}


Tabel 4. Nilai Geometric Invariant Moment untuk Cacat Distributed Porosity Dalam Perlakuan RST (Lanjutan)

\begin{tabular}{cccccccc}
\hline $\begin{array}{c}\text { Nilai } \\
\text { invarian } \\
(|\mathrm{ln}|)\end{array}$ & $\begin{array}{c}\text { Citra } \\
\text { Awal }\end{array}$ & $\begin{array}{c}\text { Pen- } \\
\text { skalaan } \\
2 \mathrm{kali}\end{array}$ & $\begin{array}{c}\text { Pen- } \\
\text { skalaan } \\
0,5 \mathrm{kali}\end{array}$ & $\begin{array}{c}\text { Rotasi } \\
30^{\circ}\end{array}$ & $\begin{array}{c}\text { Rotasi } \\
145^{\circ}\end{array}$ & $\begin{array}{c}\text { Pen- } \\
\text { cerminan } \\
\text { horisontal }\end{array}$ & $\begin{array}{c}\text { Pen- } \\
\text { cerminan } \\
\text { vertikal }\end{array}$ \\
\hline$\phi_{3}$ & 10.143 & 10.18 & 10.124 & 10.142 & 10.142 & 10.143 & 10.143 \\
$\phi_{4}$ & 9.926 & 9.9545 & 9.9125 & 9.9258 & 9.9256 & 9.926 & 9.926 \\
$\phi_{5}$ & 19.999 & 20.063 & 19.968 & 19.998 & 19.998 & 19.999 & 19.999 \\
$\phi_{6}$ & 10.359 & 10.385 & 10.347 & 11 & 11.854 & 10.36 & 10.357 \\
$\phi_{7}$ & 21.623 & 21.658 & 21.606 & 21.456 & 21.38 & 21.41 & 21.41 \\
\hline
\end{tabular}

Tabel 5. Nilai Geometric Invariant Moment untuk Cacat Clustered Porosity Dalam Perlakuan RST

\begin{tabular}{cccccccc}
\hline $\begin{array}{c}\text { Nilai } \\
\text { invarian } \\
(\ln \mid)\end{array}$ & $\begin{array}{c}\text { Citra } \\
\text { Awal }\end{array}$ & $\begin{array}{c}\text { Penskalaan } \\
2 \mathrm{kali}\end{array}$ & $\begin{array}{c}\text { Penskalaan } \\
0,5 \mathrm{kali}\end{array}$ & $\begin{array}{c}\text { Rotasi } \\
30^{\circ}\end{array}$ & $\begin{array}{c}\text { Rotasi } \\
145^{\circ}\end{array}$ & $\begin{array}{c}\text { Pencerminan } \\
\text { horisontal }\end{array}$ & $\begin{array}{c}\text { Pencerminan } \\
\text { vertikal }\end{array}$ \\
\hline$\phi_{1}$ & 1.8653 & 1.8879 & 1.8542 & 1.9435 & 0.6674 & 1.1385 & 1.8835 \\
$\phi_{2}$ & 0.0138 & 0.0242 & 0.0085 & 0.2512 & 1.154 & 0.3452 & 0.0193 \\
$\phi_{3}$ & 4.5028 & 4.4974 & 4.5054 & 4.5028 & 4.5027 & 4.5028 & 4.5028 \\
$\phi_{4}$ & 4.452 & 4.4452 & 4.4554 & 4.4521 & 4.4519 & 4.452 & 4.452 \\
$\phi_{5}$ & 8.9298 & 8.9169 & 8.9363 & 8.93 & 8.9298 & 8.9298 & 8.9298 \\
$\phi_{6}$ & 4.4482 & 4.4362 & 4.4542 & 4.9249 & 6.0937 & 4.6277 & 4.4454 \\
$\phi_{7}$ & 11.55 & 11.535 & 11.557 & 12.179 & 12.087 & 12.065 & 12.065 \\
\hline
\end{tabular}

Tabel 6. Nilai Geometric Invariant Moment untuk Cacat Wormholes

Dalam Perlakuan RST

\begin{tabular}{cccccccc}
\hline $\begin{array}{c}\text { Nilai } \\
\text { invarian } \\
(\| \mathrm{n} \mid)\end{array}$ & $\begin{array}{c}\text { Citra } \\
\text { Awal }\end{array}$ & $\begin{array}{c}\text { Penskalaan } \\
2 \mathrm{kali}\end{array}$ & $\begin{array}{c}\text { Penskalaan } \\
0,5 \text { kali }\end{array}$ & $\begin{array}{c}\text { Rotasi } \\
30^{\circ}\end{array}$ & $\begin{array}{c}\text { Rotasi } \\
145^{\circ}\end{array}$ & $\begin{array}{c}\text { Pencerminan } \\
\text { horisontal }\end{array}$ & $\begin{array}{c}\text { Pencerminan } \\
\text { vertikal }\end{array}$ \\
\hline$\phi_{1}$ & 0.5560 & 0.5637 & 0.5522 & 0.1058 & 0.2422 & 1.0421 & 0.5668 \\
$\phi_{2}$ & 0.6709 & 0.6809 & 0.6659 & 0.0496 & 0.0545 & 0.9639 & 0.6796 \\
$\phi_{3}$ & 3.0309 & 3.034 & 3.0293 & 3.0309 & 3.0308 & 3.0309 & 3.0309 \\
$\phi_{4}$ & 3.0484 & 3.0462 & 3.0495 & 3.0484 & 3.0482 & 3.0484 & 3.0484 \\
$\phi_{5}$ & 6.0948 & 6.0933 & 6.0957 & 6.0949 & 6.0945 & 6.0948 & 6.0948 \\
$\phi_{6}$ & 2.7147 & 2.7077 & 2.7183 & 3.7328 & 3.5228 & 2.5689 & 2.7104 \\
$\phi_{7}$ & 8.5049 & 8.4978 & 8.5085 & 8.5181 & 8.9318 & 7.7883 & 7.7883 \\
\hline
\end{tabular}


Tabel 7. Nilai Geometric Invariant Moment untuk Jenis Tanpa Cacat (No Defect) Dalam Perlakuan RST

\begin{tabular}{cccccccc}
\hline $\begin{array}{c}\text { Nilai } \\
\text { invarian } \\
(\ln \mid)\end{array}$ & $\begin{array}{c}\text { Citra } \\
\text { Awal }\end{array}$ & $\begin{array}{c}\text { Penskalaan } \\
2 \text { kali }\end{array}$ & $\begin{array}{c}\text { Penskalaan } \\
0,5 \text { kali }\end{array}$ & $\begin{array}{c}\text { Rotasi } \\
30^{\circ}\end{array}$ & $\begin{array}{c}\text { Rotasi } \\
145^{\circ}\end{array}$ & $\begin{array}{c}\text { Pencerminan } \\
\text { horisontal }\end{array}$ & $\begin{array}{c}\text { Pencerminan } \\
\text { vertikal }\end{array}$ \\
\hline$\phi_{1}$ & 1.4281 & 1.4404 & 1.422 & 1.052 & 0.6708 & 1.4114 & 1.4518 \\
$\phi_{2}$ & 0.1147 & 0.1279 & 0.1082 & 0.3722 & 0.8167 & 0.1071 & 0.1253 \\
$\phi_{3}$ & 10.899 & 10.943 & 10.876 & 10.898 & 10.898 & 10.899 & 10.899 \\
$\phi_{4}$ & 12.976 & 13.014 & 12.954 & 12.974 & 12.973 & 12.976 & 12.976 \\
$\phi_{5}$ & 25.04 & 25.198 & 24.966 & 25.039 & 25.037 & 25.04 & 25.04 \\
$\phi_{6}$ & 12.954 & 12.973 & 12.946 & 13.204 & 12.88 & 12.958 & 12.949 \\
$\phi_{7}$ & 25.778 & 25.7 & 25.831 & 25.805 & 26.609 & 25.305 & 25.305 \\
\hline
\end{tabular}

Berdasarkan hasil ekstraksi ciri dengan Geometric Invariant Moment untuk keenam jenis defectology yang diberikan perlakuan RST, menunjukkan bahwa nilai momen invarian yang memiliki perubahan terkecil dan mendekati konstan dari seluruh hasil pengujian adalah momen $\phi_{3}, \phi_{4}$, dan $\phi_{5}$. Sehingga nilai momen $\phi_{3}$, $\phi_{4}$, dan $\phi_{5}$ dapat digunakan sebagai nilai ciri yang dapat mewakili ciri defectology citra digital film radiografi. Selanjutnya dilakukan pengukuran nilai statistical texture dari ketiga jenis cacat pengelasan diperoleh berdasarkan data histogram yang ditunjukkan pada Gambar 4. Nilai ini diperoleh dengan membuat program atau fungsi untuk menghasilkan vektor ciri berdasarkan Persamaan (14) hingga Persamaan (18).

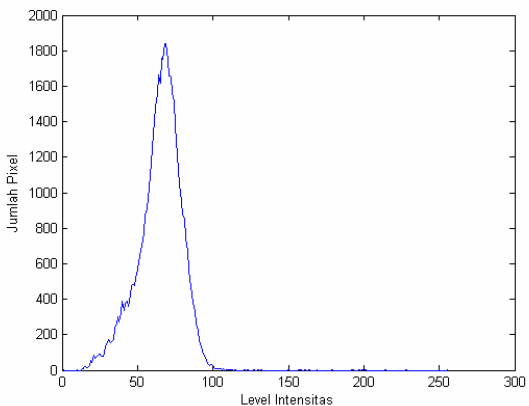

a

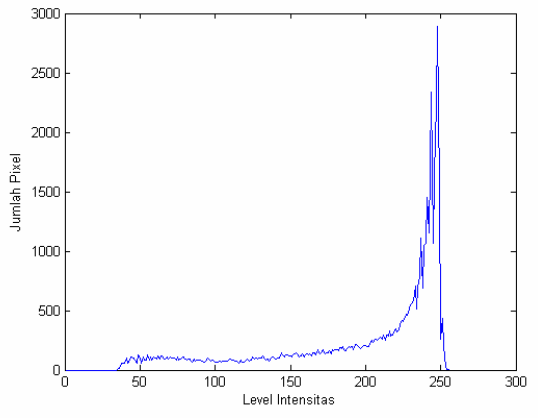

b

Gambar 4. Histogram Citra Film Radiografi (a) Longitudinal Crack, (b) Transversal Crack, (c) Distributed Porosity, (d) Clustered Porosity, (e) Wormhole, dan (f) No Defect. 


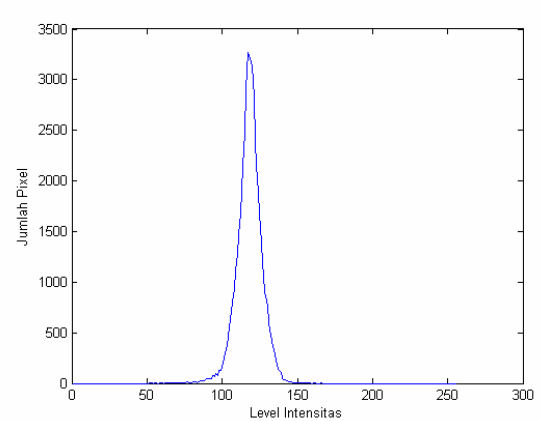

c

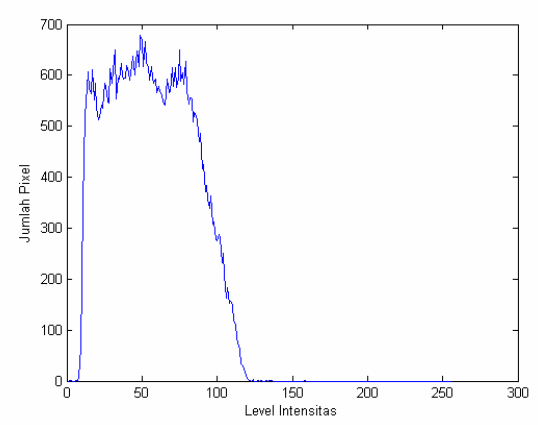

e

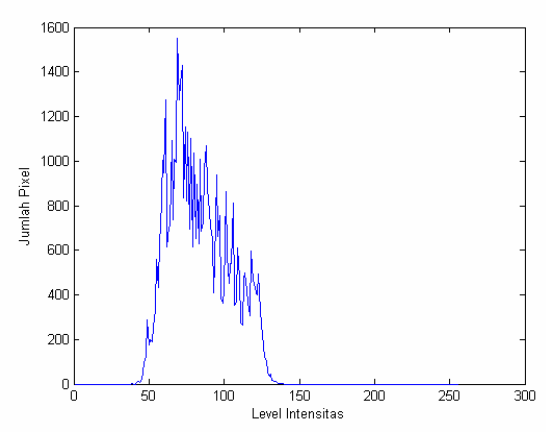

d

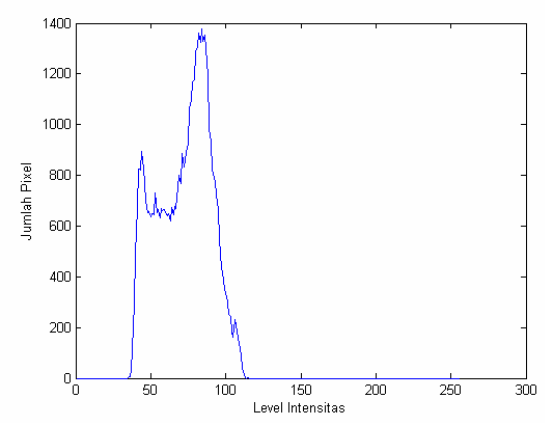

$\mathrm{f}$

Gambar 4. Histogram Citra Film Radiografi (a) Longitudinal Crack, (b) Transversal Crack, (c) Distributed Porosity, (d) Clustered Porosity, (e) Wormhole, dan (f) No Defect. (Lanjutan)

Berdasarkan histogram citra tersebut selanjutnya dihasilkan nilai ekstraksi ciri yang ditunjukkan dalam Tabel 8 .

Tabel 8. Hasil Ekstraksi Ciri dengan Statistical Texture

\begin{tabular}{|c|c|c|c|c|c|c|}
\hline $\begin{array}{c}\text { Nilai } \\
\text { Tekstur }\end{array}$ & L. Crack & T. Crack & $\begin{array}{c}\text { Dist. } \\
\text { Porosity }\end{array}$ & $\begin{array}{c}\text { Clust. } \\
\text { Porosity }\end{array}$ & Wormhole & $\begin{array}{c}\text { No } \\
\text { Defect }\end{array}$ \\
\hline $\begin{array}{c}\text { Intensitas } \\
\text { rerata }\end{array}$ & 63709 & 198.47 & 117.06 & 82.774 & 54.884 & 71.418 \\
\hline $\begin{array}{c}\text { Kontras } \\
\text { rerata }\end{array}$ & 1399 & 58.52 & 8.2543 & 19.892 & 6.706 & 17.651 \\
\hline $\begin{array}{c}\mathrm{R} \\
\text { (smoothness) }\end{array}$ & 0.003178 & 0.05003 & 0.001047 & 0.006048 & 0.01085 & 0.004768 \\
\hline $\begin{array}{l}\text { Momen } \\
\text { ketiga }\end{array}$ & -0.009938 & -3.921 & $\begin{array}{c}- \\
0.003802\end{array}$ & 0.04808 & 0.043497 & -0.01627 \\
\hline Uniformity & & 0 . & 0.03849 & 0.01 & & 0.01661 \\
\hline Entropy & 5.8115 & 6.8808 & 5.037 & 6.192 & 6.6522 & 6.0311 \\
\hline
\end{tabular}


Histogram menunjukkan bahwa tiap jenis cacat memiliki pola histogram yang berbeda, sehingga dengan mencari nilai-nilai statistik dari histogram tersebut dapat mewakili ciri dari tiap jenis cacat.

Nilai yang diperoleh dari metode statistical texture untuk ekstraksi ciri ini dipilih keenam nilai karena keenam nilai tersebut mampu menghasilkan nilai yang berbeda untuk mewakili dari masing-masing jenis cacat pengelasan. Sehingga dengan demikian seluruh nilai ekstraksi ciri dengan kedua metode tersebut dapat digunakan sebagai ciri yang mewakili jenis cacat film radiografi.

Berdasarkan metode geometric invariant moment dan statistical texture, maka diperoleh nilai-nilai yang dapat digunakan untuk melakukan ekstraksi ciri yaitu moment $\phi_{3}, \phi_{4}, \phi_{5}$, intensitas rerata , kontras rerata, smoothness, $3^{\text {rd }}$ moment, uniformity, dan entropy.

Nilai ciri ini dapat digunakan untuk melakukan pengenalan pola cacat pengelasan pada sistem interpretasi cacat pengelasan yang dilakukan secara otomatis oleh komputer.

\section{KESIMPULAN}

Dari hasil penelitian yang diperoleh, maka dapat ditarik kesimpulan sebagai berikut :

1. Metode geometric invariant moment dan statistical texture dapat diterapkan untuk melakukan ekstraksi ciri citra digital film radiografi yaitu untuk jenis crack, porosity, wormhole, dan no-defect.

2. Nilai geometric invariant moment yang dapat membedakan jenis cacat pengelasan dengan perlakuan RST paling baik adalah nilai momen $\phi_{3}$, $\phi_{4}, \phi_{5}$.

3. Seluruh nilai statistical texture dapat digunakan sebagai nilai ciri jenis cacat pengelasan.

4. Diperoleh sembilan nilai untuk ekstraksi ciri cacat pengelasan film radiografi yaitu $\phi_{3}, \phi_{4}, \phi_{5}$, intensitas rerata, kontras rerata, smoothness, $3^{\text {rd }}$ moment, uniformity, dan entropy.

\section{DAFTAR PUSTAKA}

1. FUKUNAGA, K., 1990, Introduction to Statistical Pattern Recognition Second Edition, Academic Press, USA.

2. RIZON, M., YAZID, H., SAAD, P., SHAKAFF, A. Y. M., SAAD, A. R., MAMAT, M. R., YAACOB, S., DESA, H., KARTHIGAYAN, M., 2006, "Object Detection using Geometric Invariant Moment", American Journal of Applied Science 2 (6), USA. 
3. CASTlEMAN, K. R., 1996, Digital Image Processing, Prentice Hall Inc., New Jersey.

4. GONZALES, R. C., WOODS, R. E., 2008, Digital Image Processing Third Edition, Pearson Prentice Hall, New Jersey.

5. NACEREDDINE, N., ZELMAT, M., BELAIFA, S. S., TRIDI, S., 2005, "Weld Defect Detection in Industrial Radiography Based Digital Image Processing", Proceedings of World Academy of Science, Engineering and Technology volume 2 January 2005.

\section{LAMPIRAN}

Listing program

\section{Fungsi untuk membuka citra}



\section{Pemotongan Citra}

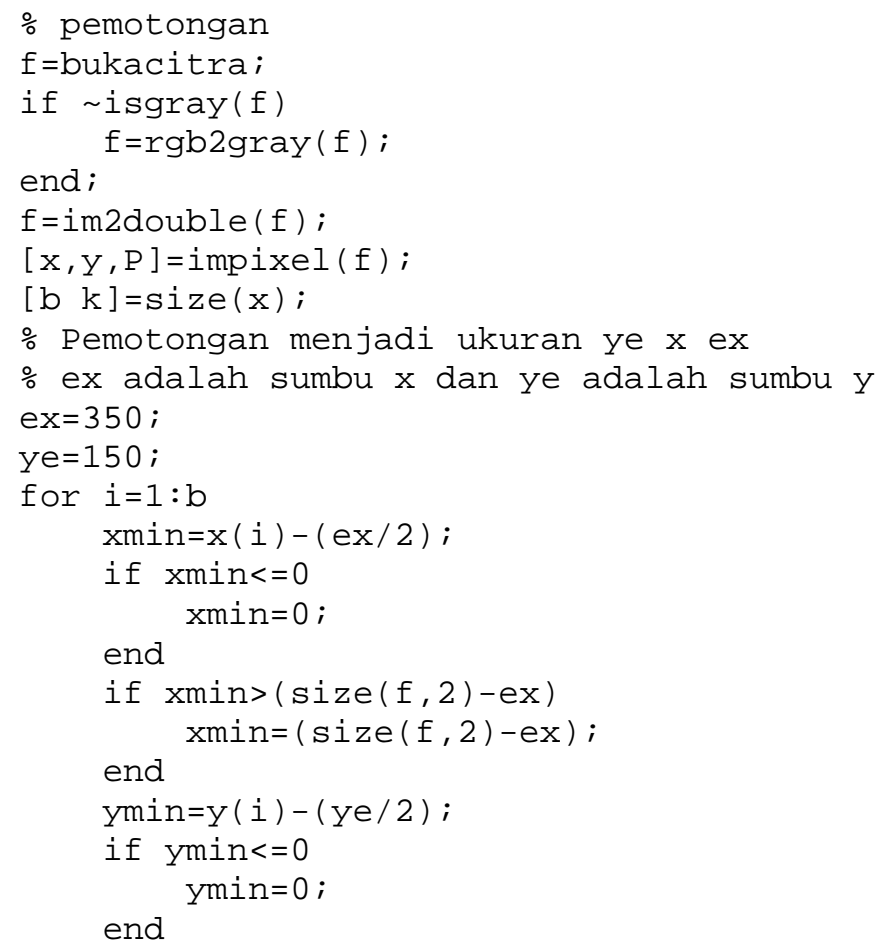




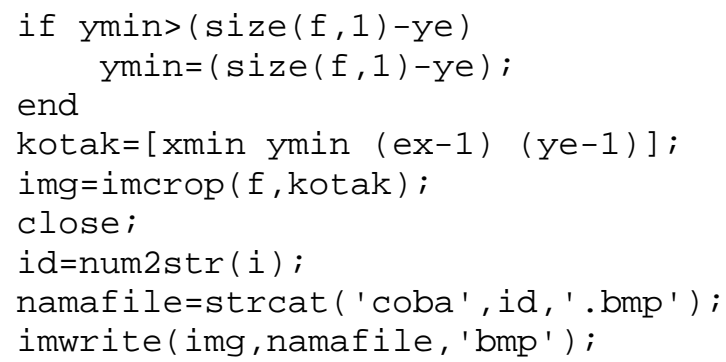

\section{Fungsi untuk mencari vector ciri dari Geometric Invariant Moment}

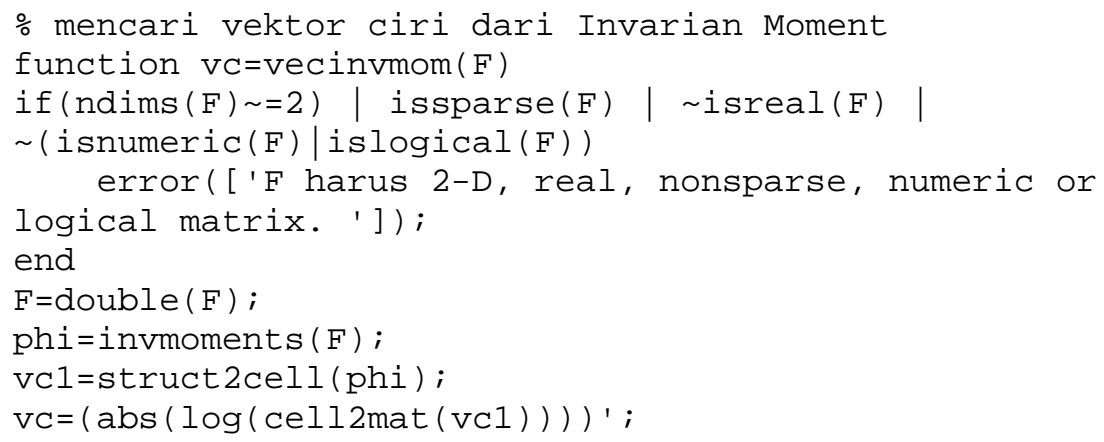

\section{Fungsi untuk menghitung Geometric Invariant Moment}

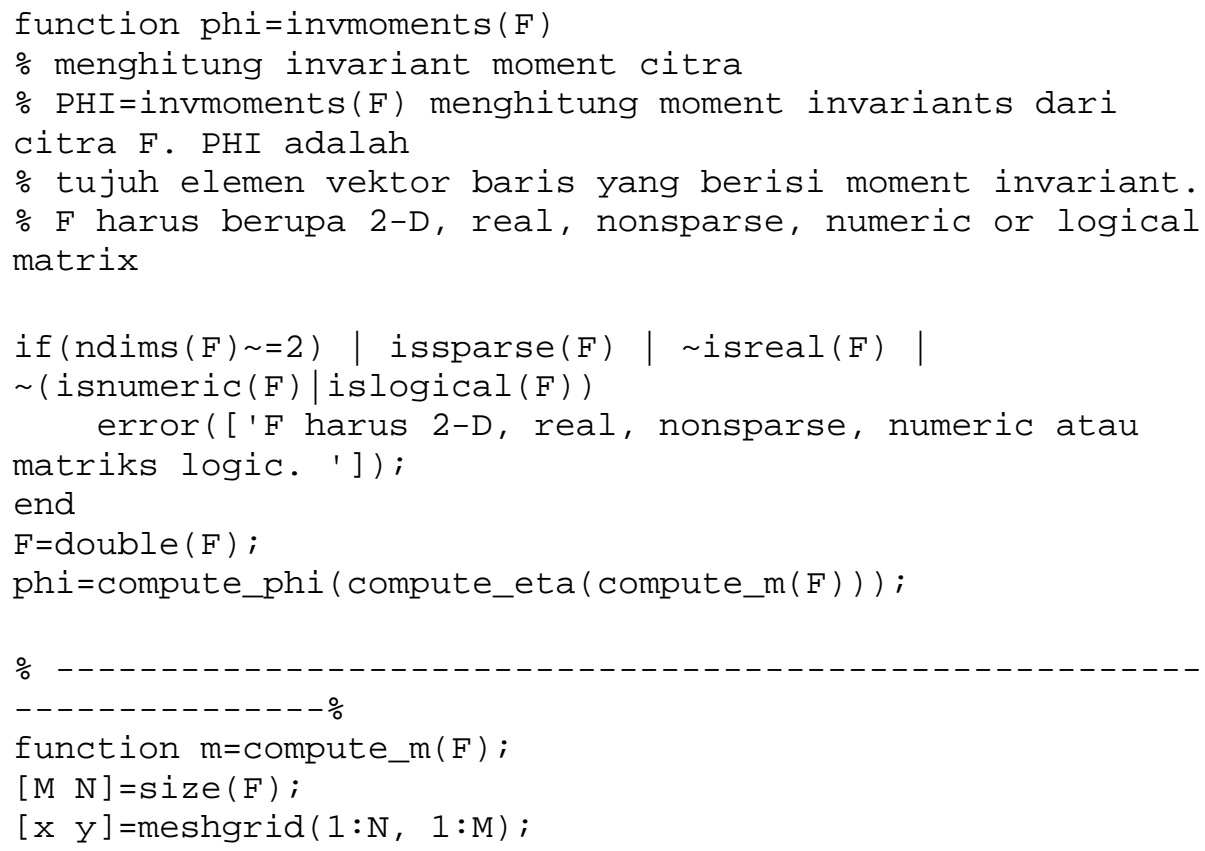


\% mengubah $\mathrm{x}, \mathrm{y}$ dan $\mathrm{F}$ menjadi vektor kolom untuk membuat penjumlahan suatu

o bit lebih mudah untuk dihitung.

$\mathrm{x}=\mathrm{x}(:)$;

$\mathrm{y}=\mathrm{y}(:) ;$

$\mathrm{F}=\mathrm{F}(:)$;

o persamaan pada DIP (11.3-12)

$\mathrm{m} \cdot \mathrm{m00}=\operatorname{sum}(\mathrm{F})$;

\% mencegah pembagian dengan nol

if $(\mathrm{m} \cdot \mathrm{m00}==0)$

end

$\mathrm{m} \cdot \mathrm{m00}=\mathrm{eps}$;

\% central moment lainnya:

$\mathrm{m} \cdot \mathrm{m} 10=\operatorname{sum}\left(\mathrm{x} \cdot{ }^{\star} \mathrm{F}\right)$;

$\mathrm{m} \cdot \mathrm{m} 01=\operatorname{sum}\left(\mathrm{y} \cdot{ }^{\star} \mathrm{F}\right)$;

$\mathrm{m} \cdot \mathrm{m} 11=\operatorname{sum}\left(\mathrm{x} \cdot{ }^{\star} \mathrm{y} \cdot{ }^{\star} \mathrm{F}\right)$;

$\mathrm{m} \cdot \mathrm{m} 20=\operatorname{sum}\left(\mathrm{x} \cdot{ }^{\wedge} 2 \cdot{ }^{\star} \mathrm{F}\right)$;

$\mathrm{m} \cdot \mathrm{m} 02=\operatorname{sum}\left(\mathrm{y} \cdot{ }^{\wedge} 2 \cdot{ }^{\star} \mathrm{F}\right)$;

$\mathrm{m} \cdot \mathrm{m} 30=\operatorname{sum}\left(\mathrm{x} \cdot \wedge 3 \cdot{ }^{\star} \mathrm{F}\right)$;

$\mathrm{m} \cdot \mathrm{m} 03=\operatorname{sum}\left(\mathrm{y} \cdot{ }^{\wedge} 3 \cdot{ }^{\star} \mathrm{F}\right)$;

$\mathrm{m} \cdot \mathrm{m} 12=\operatorname{sum}\left(\mathrm{x} \cdot{ }^{\star} \mathrm{y} \cdot{ }^{\wedge} 2 \cdot{ }^{\star} \mathrm{F}\right)$;

$\mathrm{m} \cdot \mathrm{m} 21=\operatorname{sum}\left(\mathrm{x} \cdot{ }^{\wedge} 2 \cdot{ }^{\star} \mathrm{y} \cdot{ }^{\star} \mathrm{F}\right)$;

응

$-----------------\frac{\circ}{0}$

function e=compute_eta $(\mathrm{m})$

\% persamaan DIP $11.3-14 \mathrm{~s} / \mathrm{d} 11.3-16$

$\mathrm{xbar}=\mathrm{m} \cdot \mathrm{m} 10 / \mathrm{m} \cdot \mathrm{m} 00$;

$\mathrm{ybar}=\mathrm{m} . \mathrm{m} 01 / \mathrm{m} \cdot \mathrm{m00}$;

e.eta $11=\left(\mathrm{m} \cdot \mathrm{m} 11-\mathrm{ybar}^{\star} \mathrm{m} \cdot \mathrm{m} 10\right) / \mathrm{m} \cdot \mathrm{m00} 0^{\wedge} 2$;

e.eta $20=\left(\mathrm{m} \cdot \mathrm{m} 20-\mathrm{xbar}{ }^{\star} \mathrm{m} \cdot \mathrm{m} 10\right) / \mathrm{m} \cdot \mathrm{m00} 0^{\wedge} 2 ;$

e.eta $02=\left(\mathrm{m} \cdot \mathrm{m} 02-\mathrm{ybar}^{\star} \mathrm{m} \cdot \mathrm{m} 10\right) / \mathrm{m} \cdot \mathrm{m00} 0^{\wedge} 2$;

e.eta $30=\left(\mathrm{m} . \mathrm{m} 30-3{ }^{\star} \mathrm{xbar}{ }^{\star} \mathrm{m} . \mathrm{m} 20+2{ }^{\star} \mathrm{xbar} \mathrm{r}^{\star}{ }^{\star} \mathrm{m} \cdot \mathrm{m} 10\right) / \mathrm{m} \cdot \mathrm{m} 00^{\wedge} 2.5$;

e. eta03 $=\left(\mathrm{m} . \mathrm{m} 03-3{ }^{*} \mathrm{ybar}^{\star} \mathrm{m} \cdot \mathrm{m} 02+2{ }^{\star} \mathrm{ybar}^{\wedge} 2{ }^{\star} \mathrm{m} \cdot \mathrm{m} 01\right) / \mathrm{m} \cdot \mathrm{m0} 00^{\wedge} 2 \cdot 5$;

e.eta $21=(m \cdot m 21-2 * x b a r * m \cdot m 11-$

$\left.\mathrm{ybar}{ }^{*} \mathrm{~m} \cdot \mathrm{m} 20+2 * \mathrm{xbar}^{\wedge} 2{ }^{*} \mathrm{~m} \cdot \mathrm{m} 01\right) / \mathrm{m} \cdot \mathrm{m} 00^{\wedge} 2.5$;

e. eta $12=(m \cdot m 12-2 * y b a r * m \cdot m 11-$

$\left.\mathrm{xbar}{ }^{\star} \mathrm{m} \cdot \mathrm{m} 02+2{ }^{*} \mathrm{ybar}^{\wedge} 2{ }^{*} \mathrm{~m} \cdot \mathrm{m} 10\right) / \mathrm{m} \cdot \mathrm{m} 00^{\wedge} 2 \cdot 5$;

$\circ$

$----------------\frac{\circ}{0}$

function phi=compute_phi(e)

o persamaan DIP 2nd Ed 11.3-17 s/d 11.3-23 


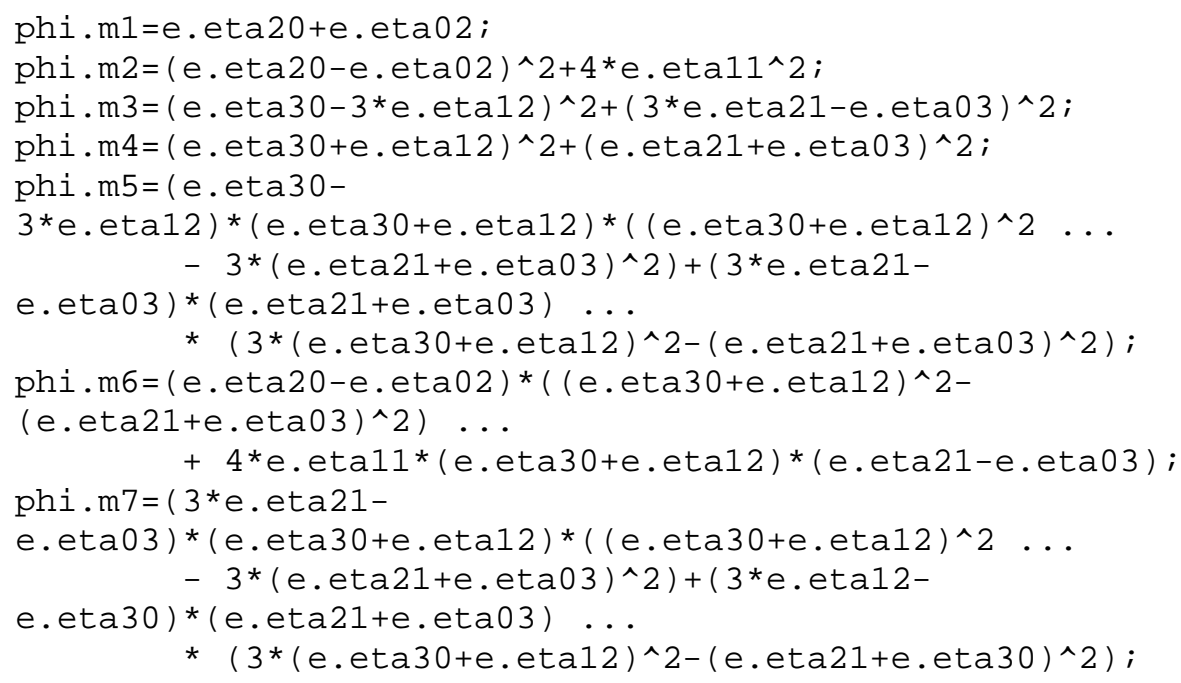

\section{Program untuk mencari vektor ciri dengan Statistical Texture}

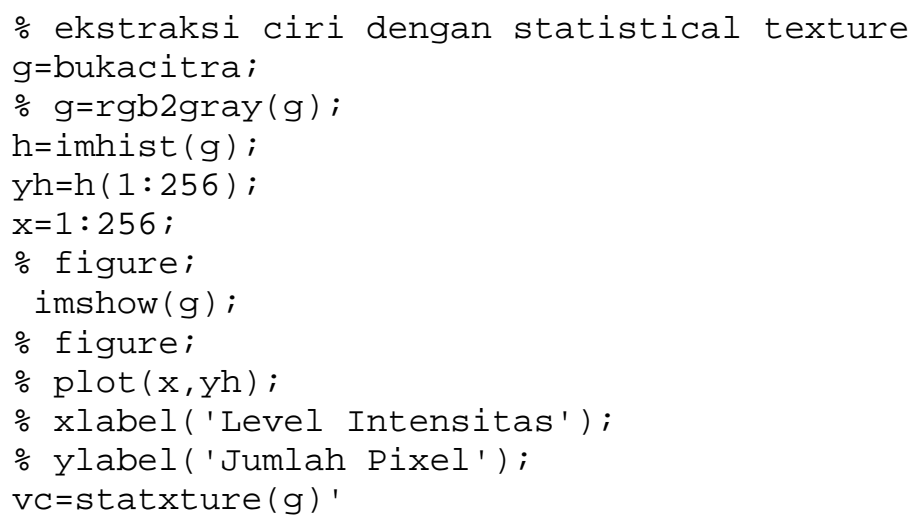

\section{Fungsi Menghitung nilai Statistical Texture}

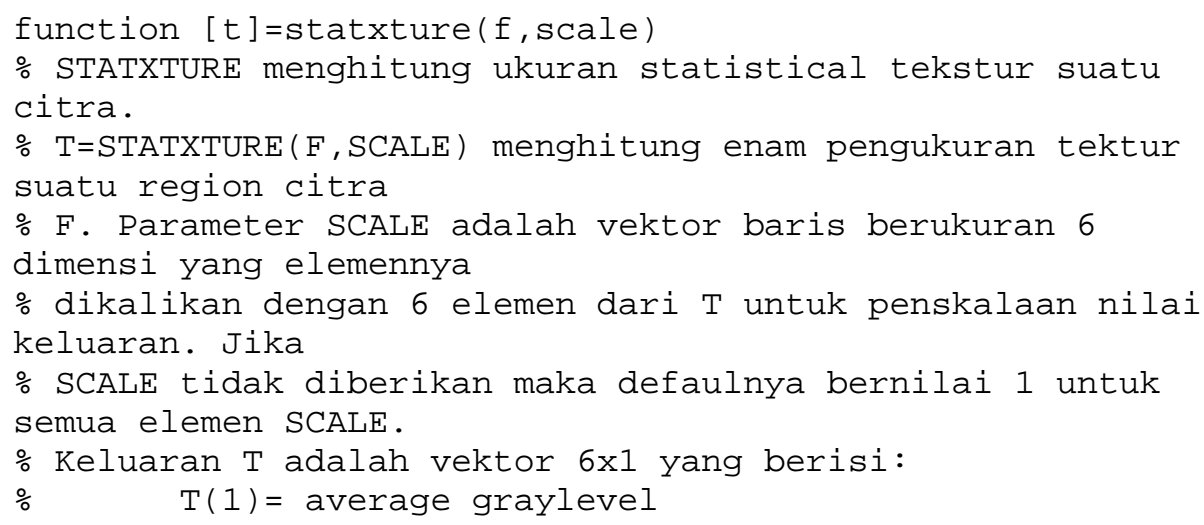




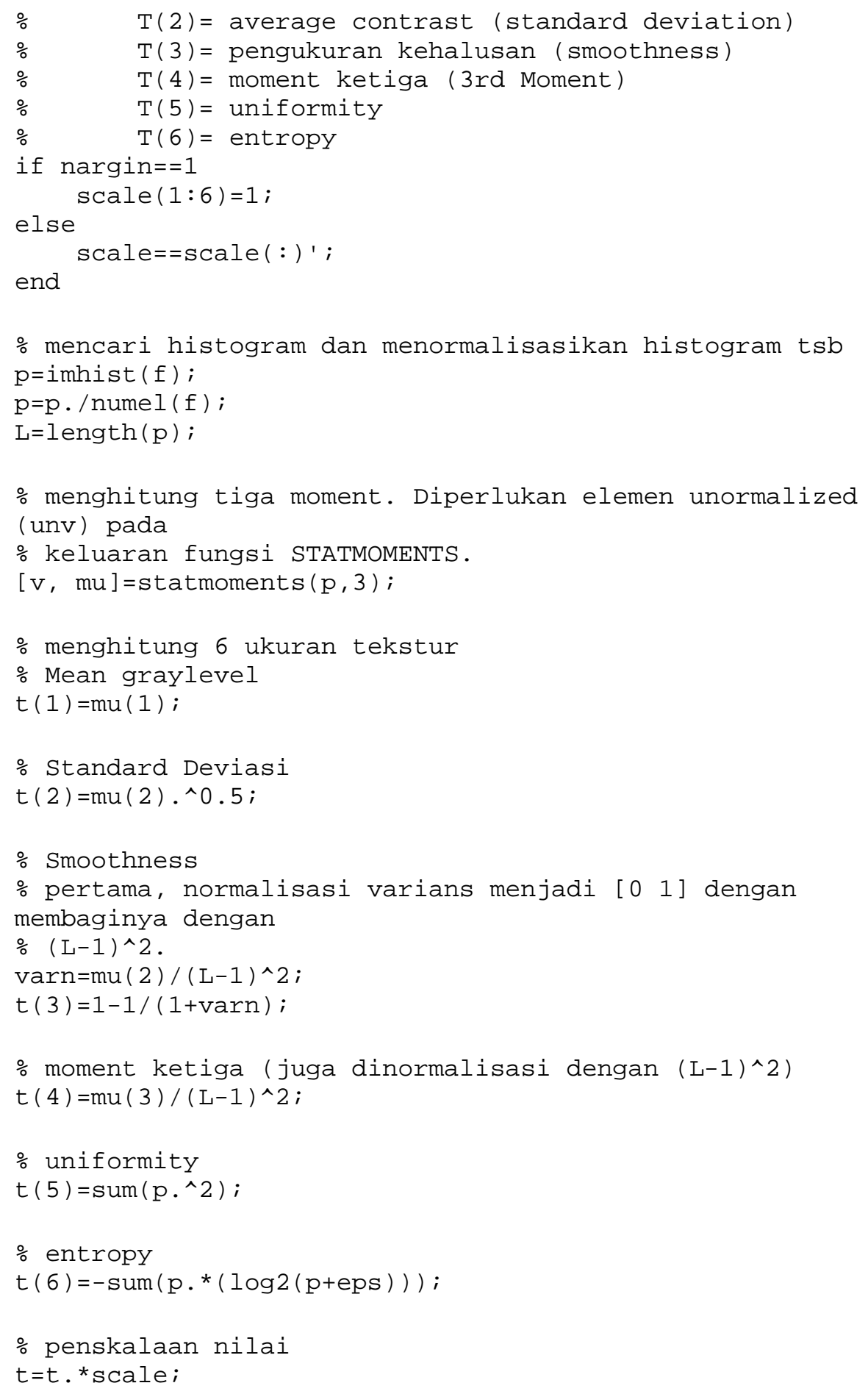




\section{Fungsi statmoment}

function $[\mathrm{v}$, unv $]=$ statmoments $(\mathrm{p}, \mathrm{n})$

o STATMOMENTS digunakan untuk menghitung statistik

central moment dari

\% histogram citra

$\circ[\mathrm{V}, \mathrm{UNV}]=\operatorname{STATMOMENTS}(\mathrm{P}, \mathrm{N})$ meghitung $\mathrm{N}$ buah momen pusat statistik

o (Statistical Central Moments) suatu histogram yang mana komponen-komponen

o adalah pada vektor P. Panjang P harus sama dengan 255 atau 65535

․ .

o keluaran program adalah vektor $\mathrm{V}$ dengan :

$\div \mathrm{V}(1)=$ mean;

$\div \quad V(2)=$ variance;

$\therefore \quad V(3)=3 r d$ moment

$\circ \mathrm{V}(\mathrm{N})=$ moment ke $\mathrm{N}$.

o Nilai Variabel random dinormalisasi pada range [0 1], sehingga semua

\% moment berada pada range ini

$\div$

\% Program juga mengeluarkan vektor UNV yang mengandung sama dengan $\mathrm{V}$, namun

o tanpa normalisasi variabel random (yaitu 0 s/d 255 untuk

$\div$ length $\left.(P)=2^{\wedge} 8\right)$. Contoh, jika length $(P)=256$ dan

$\mathrm{V}(1)=0.5$, maka UNV(1) akan

응 bernilai UNV(1)=127.5 (setengah dari rentang [0 255]).

Lp=length $(\mathrm{p})$;

if $(\mathrm{Lp} \sim=256) \&(\mathrm{Lp} \sim=65536)$

error('P harus antara berupa vektor 256 atau 65536

element');

end

$\mathrm{G}=\mathrm{Lp}-1$;

o Pastikan histogram mempunyai unit area, dan dikonversi kedalam vektor

o kolom;

$\mathrm{p}=\mathrm{p} / \operatorname{sum}(\mathrm{p})$;

$\mathrm{p}=\mathrm{p}(:) ;$

\% Bentuk sebuah vektor dari semua nilai yang mungkin dari variabel random $\mathrm{z}=0: \mathrm{G}$;

№rmalisasi z keadalam range [ $\left.\begin{array}{ll}0 & 1\end{array}\right]$. 


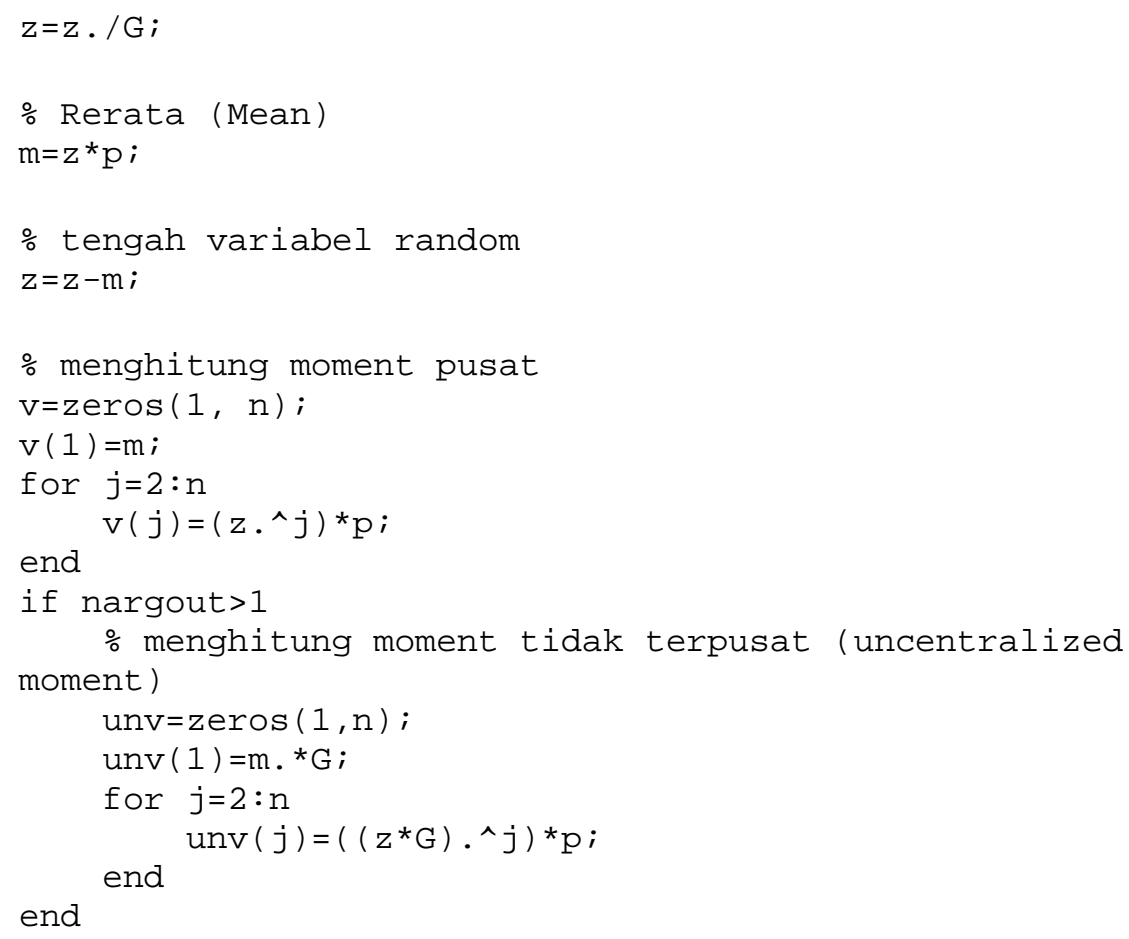

Program untuk melakukan Operasi RST (Rotating, Scaling, Translation)

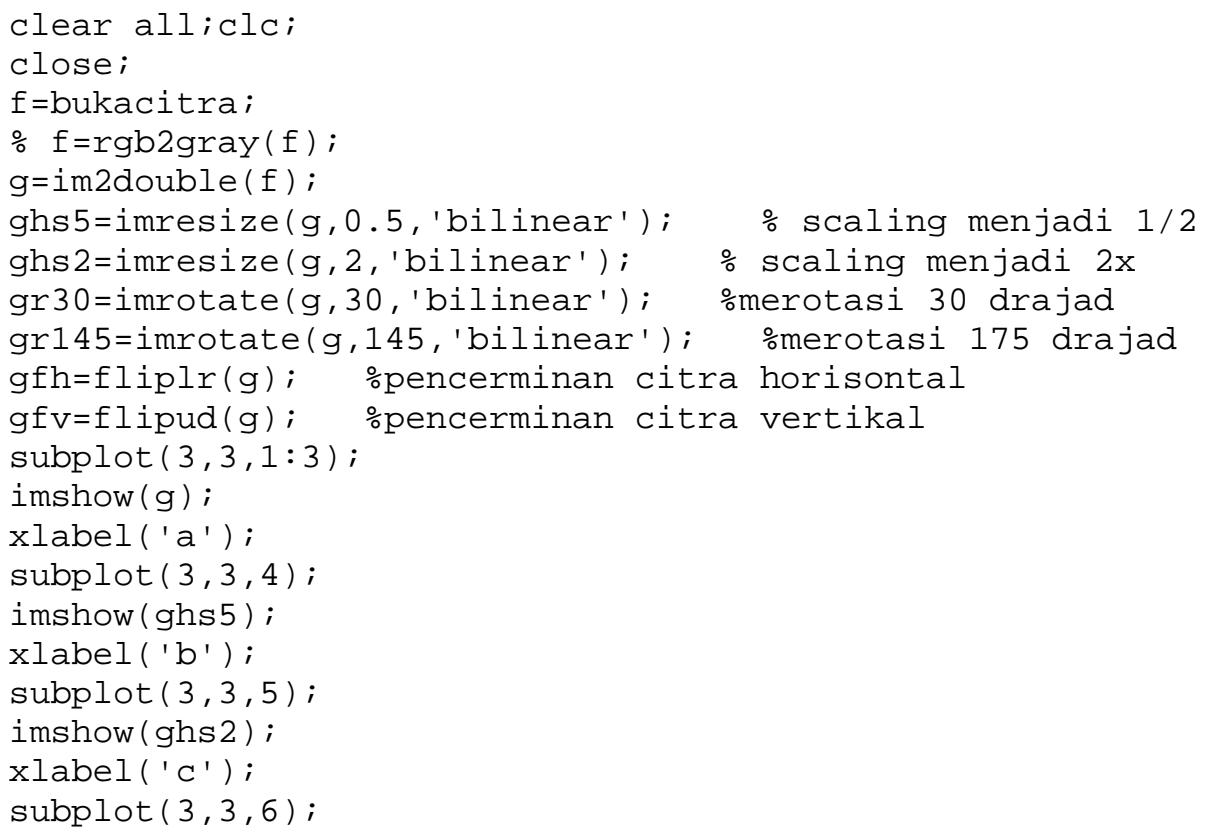




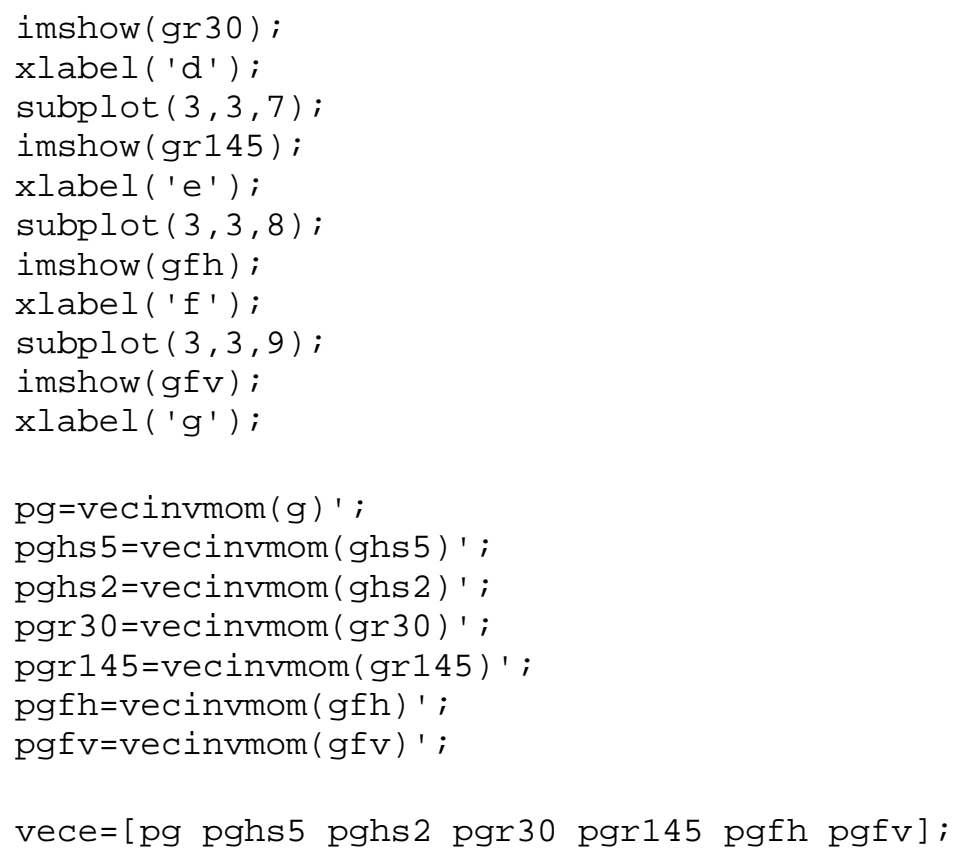


